\title{
IMPLEMENTASI LKS TABELA UNTUK MENINGKATKAN KETERAMPILAN PROSES SAINSSISWA SD
}

\section{Implementation of LKS Tabela to Improve Skills of Elementary School Student Science Processes}

\section{Rita Rahmaniati*}

Universitas Muhammadiyah

Palangkaraya, Palangka Raya,

Central Kalimantan, Indonesia

*email:

rahmaniatirita@gmail.com

\section{Kata Kunci:}

Tabela LKS

Keterampilan Proses Sains

\section{Keywords:}

Tabela LKS

Science Process Skills

\begin{abstract}
Abstrak
Penelitian ini bertujuan untuk (I) Untuk mendeskripsikan kegiatan proses sains siswa kelas $\mathrm{V}$ SD Muhammadiyah Palangkaraya selama pembelajaran dengan menggunakan LAB Tabela (3) untuk mengetahui peningkatan proses sains siswa sekolah dasar Muhammadiyah di kota Palangkaraya. Subjek dalam penelitian ini adalah semua siswa kelas 27 SD Muhammadiyah di Palangkaraya, Kalimantan Tengah. Metode penelitian yang digunakan oleh peneliti adalah menggunakan metode penelitian tindakan kelas dengan dua siklus. Teknik analisis dalam penelitian ini menggunakan analisis data kualitatif dan kuantitatif. Hasil penelitian menunjukkan bahwa aktivitas proses sains siswa dalam pembelajaran menggunakan LKS Tabela rata-rata 2,92 sudah cukup pada siklus I dan siklus II kategori sangat baik adalah skor rata-rata 3,79 , dan hasil tes proses sains menunjukkan peningkatan dari rata-rata pretes 59,75 menjadi rata-rata 89,5 pada posttest, $N$ naik 0,82 dalam kategori tinggi. Melalui pembelajaran dengan menggunakan Tabela LKS mampu meningkatkan hasil belajar dan keterampilan proses sains siswa.
\end{abstract}

\begin{abstract}
The study aimed to (I) To describe the science process activities of the fifth-grade students of SD Muhammadiyah Palangkaraya during learning by using the LAB Tabela (3) to find out the improvement of science processes of Muhammadiyah elementary school students in Palangkaraya city. The subjects in this study were all 27th-grade students of Muhammadiyah Elementary School in Palangkaraya, Central Kalimantan. The research method used by researchers was to use the class action research method with two cycles. The analysis technique in this study uses qualitative and quantitative data analysis. The results of the study show that the science process activities of students in learning using the LKS Tabela on average 2.92 are sufficient in the first cycle and the second cycle the excellent category is the average score of 3.79, and the results of the science process test showed an increase from the average pretest of 59.75 to an average of 89.5 in posttest, $N$ gain of 0.82 in the high category. Through learning by using Tabela LKS able to improve learning outcomes and science process skills of students.
\end{abstract}

\section{Accepted}

September 2019

Published

December 2019

\section{PENDAHULUAN}

Proses pembelajaran pada Kurikulum dilaksanakan menyentuh tiga ranah, yaitu sikap, pengetahuan, dan keterampilan. Hasil akhir pembelajaran pada kurikulum 2013 adalah peningkatan dan keseimbangan antara kemampuan untuk menjadi manusia yang baik (soft skills) dan manusia yang memiliki kecakapan dan pengetahuan untuk hidup 
secara layak (hard skills) dari siswa yang meliput aspek kompetensi sikap, keterampilan, dan pengetahuan. Kurikulum 2013 menekankan pada dimensi pedagogik modern dalam pembelajaran, yaitu menggunakan pendekatanilmiah. Pendekatan ilmiah (scientific approach) dalam pembelajaran sebagaimana dimaksud meliputi mengamati, menanya, mencoba, mengolah, menyajikan, menyimpulkan, dan mencipta untuk semua mata pelajaran.

Berdasarkan hasil observasi di SD Muhammadiyah Palangkaraya pada peserta didikkelas $\mathrm{V}$ yang berjumlah 27 orang. Proses pembelajaran tampak bahwa guru mengajar IPA lebih dominan menyampaikan teori dan belum melaksanakan kegiatan proses ilmiah. Hal ini berdampak pada rendahnya keterampilan proses sains siswa. Rendahnya proses sainssiswa dapat mempengaruhi kemampuan siswa untuk berfikir secara kritis, kreatif dan inovatif, Siswa mudah terpengaruh oleh pendapat orang lain, menghindari masalah, memecahkan masalah tanpa berfikir yang mendalam, belum dapat memecahkan masalah sendiri, dan merasa rendah diriapabila harus berbeda dengan orang lain. Jika kondisi tersebut dibiarkan berlarut larut dan tidak segeradi perbaiki, maka akan berdampak pula pada hasil belajar siswa secara keseluruhan.

Pembelajaran dengan pendekatan ilmiah dapat dilakukan dengan menggunakan LKS (LembarKerjaSiswa) Tabelayang didalamnya terdapat langkah langkah proses sains. LKS yang sesuai dengan pendekatan keterampilan proses mampu menumbuhkan kemampuan berpikir kritis, bekerja dan bersikap ilmiah serta mengomunikasikannya sebagai aspek penting kecakapan hidup, sehingga lebih menekankan pada pemberian pengalaman belajar secara langsung. LKS Tabela berbasis bahan lokal salah satubahan ajar yang dapat di gunakan guru untuk melatih keterampilan proses sainssiswa..LKS "Tabela" merupakan akronim dari bahasa Dayak yang berarti muda. LKS Tabela Berbasis Bahan Praktikum Lokal dimaksudkan disini adalah seperangkat LKS yang di desain sesuai dengan karakteristik siswa SD yang masih muda dan memiliki imajinasi tinggi dengan berbagai potensi yang berbeda yang mencoba mengaitkan bahan/sumber belajarnya dengan bahan praktikum lokal khususnya di Kalimantan Tengah.

\section{KAJIAN TEORI}

Lembar Kerja Siswa (LKS) merupakan suatu bahan ajar cetak berupa lembar-lembar kertas yang berisi materi, ringkasan, dan petunjuk-petunjuk pelaksanaan tugas pembelajaran yang harus dikerjakan oleh peserta didik, yang mengacu pada kompetensi dasar yang harus dicapai (Prastowo, 20II).

Menurut Hasjim (200I) LKS adalah lembar yang digunakan untuk mengarahkan dalam bentuk kerja, praktek atau dalam bentuk penerapan hasil belajar untuk mencapai suatu tujuan.

Menurut Lestari (2013) Lembar Kerja Siswa (LKS) adalah materi ajar yang sudah dikemas sedemikian rupa, sehingga siswa diharapkan dapat mempelajari materi ajar tersebut secara mandiri. Dalam LKS siswaakanmendapatkanmateriringkasan dan tugas yang berkaitan dengan materi.

Pengertian beberapa ahli diatas dapat disimpulkan bahwa LKS merupakan materi ajar cetak yang dikemassedemikian rupa yang berisimateri, ringkasan, dan petunjuk-petunjuk pelaksanaan tugas pembelajaran yang harus dikerjakan, oleh peserta didik sehingga siswa dapat belajar secara mandiri.

Fungsi LKS sebagai panduan untuk latihan pengembangan aspek kognitif maupun semua aspek pembelajaran dalam bentuk panduan percobaan atau demonstrasi (Trianto, 2009). Sedangkan menurut Prastowo (2012) fungsi LKS yaitu sebagai bahan ajar yang bias meminimalkan peran pendidik dan lebih mengatifkan peserta didik, sebagai bahan ajar yang memudahkan peserta didik untuk memahami materi yang diberikan sertak ompetensi keterampilannya, 
sebagai bahan ajar yang ringkas dan mengandung unsure melatih keterampilan siswa, dan memudahkan pelaksanaan pembelajaran.

Tujuanpenyusunan LKS menurutPrastowo (20I2) adalah I) menyajikan bahan ajar yang memudahkan peserta didik untuk berinteraksi dengan materi yang diberikan: 2) menyajikan tugas-tugas dan langkah-langkah kerja untuk meningkatkan penguasaan materi oleh pesertadidik; 3) melatih kemandirian pesertadidik dalam belajar; 4) memudahkan pendidik dalam mendampingi proses pembelajaran.

Dari pendapat diatas dapat diambil kesimpulan bahwa fungsi dan tujuan penyususnan lembar kerjasiswa yaitu sebagai bahan ajar yang memudahkan peserta didik untuk memahami materi yang mengandung unsure pengembangan aspekognitif yang berisi prosedur kerja untuk meningkatkan pemahaman materi dan keterampilan.

LKS terdiri dari enamunsurutama yang meliputi: (I) judul, (2) petunjuk belajar, (3) kompetensi dasar atau materi pokok, (4) informasi pendukung, (5) tugas atau langkah kerja, dan (6) penilaian.

Sedangkan dilihat dari formatnya, LKS memuat paling tidak delapan unsur yaitu (I) judul, (2) kompetensi dasar yang akan dicapai, (3) waktu penyelsaian, (4) peralatan atau bahan yang diperlukan untuk menyelesaikan tugas, (5) informasi singkat, (6) langkah kerja, (7) tugas yang dilakukan, dan (8) laporan yang di kerjakan.

Kelebihan dan kekurangan LKS menurut Kemp \& Dayton dalam Azhar Arsyad (2014) diantaranya: I) peserta didik dapat belajar dan maju sesuai dengan kecepatan masing-masing; 2) peserta didik dapat mengulang belajar sendiri materi yang sudah disampaikan pada saat teori; 3) perpaduan teks dan gmbar bisa menambah daya tarik sehingga memperlancar penyampaian informasi yang disajikan dalam format verbal dan visual; 4) peserta didik akan lebih aktif berpartisipasi karena harus memberikan respon terhadap latihan dan pertanyaan yang disusun; dan 5) media cetak ulang dan disebar dengan mudah. Sedangkan kekurangannya yaitu : I) biaya percetakan mahal jika akan menampilkan gambar yang berwarna; 2) proses percetakan seringkali memakan waktu; 3) penyusunan dirancang sedemikian rupa agar tidak terlalu panjang; 4) membutuhkan perawatan yang lebih baik; dan 5) tidak bisa menampilkan gerak.

Keterampilan proses sains adalah semua keterampilan yang diperlukan untuk memperoleh, mengembangkan, dan menerapkan konsep-konsep, hukum-hukum, dan teori-teori IPA, baik berupa keterampilan mental, keterampilan fisik maupun keterampilan sosial ( Rustaman,2005).

Menurut Dimyati dan Mudjiono (2009) Keterampilan proses sainas terdiri atas keterampilan-keterampilan dasar (basic skills) dan keterampilan-keterampilan terintegrasi (integrated skills). Keterampilanketerampilan dasar meliputi enam keterampilan, yakni mengobservasi, mengklasifikasi, memprediksi, mengukur, menyimpulkan dan mengkomunikasikan. Sedangkan keterampilan-keterampilan terintegrasi terdiri atas mengidentifikasi variabel, membuat tabulasi data, menyajikan data dalam bentuk grafik, menggambarkan hubungan antar variabel, mengumpulkan dan mengolah data, menganalisis penelitian, menyusun hipotesis, mendefinisikan variabel secara operasional, merancang penelitian dan melaksanakan eksperimen.

Keterampilan proses sains sebagai pendekatan dalam pembelajaransangatpentingkarenamenumbuhkanpengal amanselain proses belajar. Mengingat semakin banyaknya sekolah yang telah memiliki laboratorium biologi, sehingga perlu upaya meningkatkan efektivitas pembelajaran, khususnya prestasi hasil belajar kognitif yang didukung oleh keterampilan serta sikap dan prilaku yang baik. Oleh karena itu para guru hendaknya secara bertahap mulai bergerak melakukan penilaian hasil belajar dalam aspek keterampilan dan sikap (Rustaman, 2005). 
MenurutNuh (2010), ada beberapahal yang mempengaruhi keterampilan proses sains yang dituntut untuk dimiliki siswa. Faktor yang berpengaruh terhadap keterampilan proses sains, di antaranya yaitu perbedaan kemampuan siswa secara genetik, kualitas guru serta perbedaan strategi guru dalam mengajar. Indikator keterampilan proses sains dijabarkan pada Tabel I.

Tabel I.

Indikator Keterampilan Proses Sains

\begin{tabular}{|c|c|}
\hline $\begin{array}{c}\text { Keterampilan Proses } \\
\text { Sains }\end{array}$ & Indikator \\
\hline Mengamati(observasi) & $\begin{array}{ll}\text { 1. } & \text { Menggunakan sebanyak } \\
\text { mungkin indera } \\
\text { 2. } & \text { Mengumpulkan atau } \\
\text { menggunakan fakta yang } \\
\text { relevan }\end{array}$ \\
\hline Mengelompokkan(Klasifikasi) & 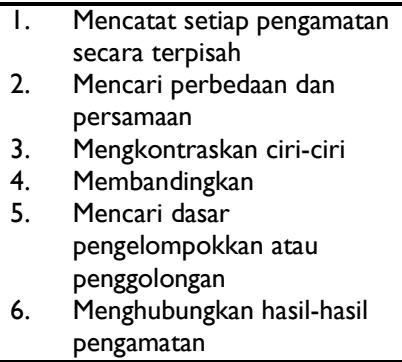 \\
\hline $\begin{array}{l}\text { Menafsirkan } \\
\text { (Interpretasi) }\end{array}$ & $\begin{array}{l}\text { I. Menghubungkan hasil-hasil } \\
\text { pengamatan } \\
\text { 2. Menemukan pola dalam } \\
\text { suatu seri pengamatan } \\
\text { 3. Menyimpulkan }\end{array}$ \\
\hline $\begin{array}{l}\text { Meramalkan } \\
\text { (Prediksi) }\end{array}$ & $\begin{array}{ll}\text { 1. } & \text { Menggunakan pola-pola hasil } \\
\text { pengamatan } \\
\text { 2. } \\
\text { Mengemukakan apa yang } \\
\text { mungkin terjadi pada } \\
\text { keadaan yang belum diamati }\end{array}$ \\
\hline Mengajukan pertanyaan & $\begin{array}{ll}\text { I. } & \text { Bertanya apa, bagaimana, } \\
\text { dan mengapa } \\
\text { 2. Bertanya untuk meminta } \\
\text { 3enjelasan } \\
\text { 3. } \begin{array}{l}\text { Mengajukan pertanyaan yang } \\
\text { berlatar belakang hipotesis }\end{array}\end{array}$ \\
\hline Berhipotesis & $\begin{array}{ll}\text { I. } & \begin{array}{l}\text { Mengetahui bahwa ada lebih } \\
\text { dari satu kemungkinan }\end{array} \\
\text { penjelasan dari satu kejadian } \\
\text { 2. Menyadari bahwa suatu } \\
\text { penjelasan perlu diuji } \\
\text { kebenarannya dalam } \\
\text { memperoleh bukti lebih } \\
\text { banyak }\end{array}$ \\
\hline Merencanakan Eksperimen/ & 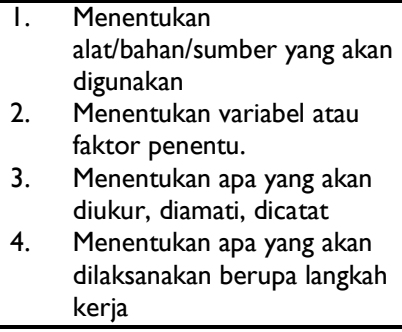 \\
\hline Menggunakan alat/bahan & $\begin{array}{ll}\text { I. } & \text { Memakai alat dan bahan } \\
\text { 2. } & \text { Mengetahui alasan mengapa } \\
\text { 3. } & \text { Menggunakan alat/bahan } \\
\text { 3. } & \text { Mengetahui bagaimana }\end{array}$ \\
\hline
\end{tabular}

\begin{tabular}{|c|c|}
\hline Keterampilan Proses & Indikator \\
\hline & menggunakan alat dan bahan \\
\hline Menerapkan konsep & $\begin{array}{ll}\text { I. } & \text { Menggunakan konsep yang } \\
\text { telah dipelajari dalam situasi } \\
\text { baru }\end{array}$ \\
\hline Berkomunikasi & 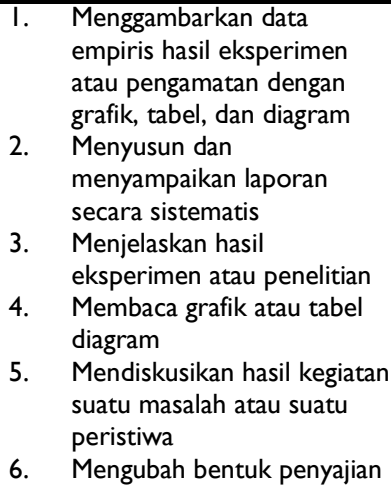 \\
\hline
\end{tabular}

\section{HASIL PENELITIAN}

I. Aktivitas Proses SainsSiswa

Data aktivitas

proses

sainssiswaselamapembelajarandiamatioleh 2 orang observer. Data aktivitas proses sainssiswadisajikan pad tabelberikut

\section{Tabel I Aktivitas proses}

\section{sainssiswa}

\begin{tabular}{|c|l|c|c|}
\hline NO & \multicolumn{1}{|c|}{$\begin{array}{c}\text { Keterampilan Proses } \\
\text { Sains }\end{array}$} & $\begin{array}{c}\text { Rata-rata observer } \\
\text { Siklus I }\end{array}$ & $\begin{array}{c}\text { Rata-rata } \\
\text { observer } \\
\text { Siklus II }\end{array}$ \\
\hline I & $\begin{array}{l}\text { Membuat rumusan } \\
\text { masalah }\end{array}$ & 2,75 & 3,50 \\
\hline 2 & Membuat hipotesis & 2,5 & 3,75 \\
\hline 3 & $\begin{array}{l}\text { Menggunakan alat } \\
\text { bahan }\end{array}$ & 3,25 & 4 \\
\hline 4 & $\begin{array}{l}\text { Menyusun prosedur } \\
\text { kerja }\end{array}$ & 3 & 3,5 \\
\hline 5 & $\begin{array}{l}\text { Berkomunikasi } \\
\text { (membuat tabel) }\end{array}$ & 3 & 4 \\
\hline 6 & Menganalisis Data & 3,5 & 3,75 \\
\hline 7 & Kesimpulan & 2,5 & 26,5 \\
\hline \multicolumn{2}{r}{ Jumlah } & 20,5 & 3,79 \\
\hline
\end{tabular}

Keterangan Skor:

$$
\begin{array}{ll}
- & 4 \text { = sangat baik } \\
- & 3 \text { = baik } \\
- & 2 \text { = kurang baik } \\
- & 1=\text { tidak baik }
\end{array}
$$

Berdasarkantabeldiatas, aktivitas proses sainssiswa SD Muhammadiyah pada pembelajaranmenggunakan LKS Tabelamenunjukkanperkembangan yang baik. Aktivitas 
proses sains pada siklus I rata-rata skor 2,92 (cukup) Sedangkan pada siklus II ada peningkatan menjadi baik dengan nilai rata- rata skor 3,79 (baik). Peserta didik yang awalnya tidak terbiasa dalam melakukan aktivitas sains pada siklus I perlahan-lahan menunjukkan perkembangan lebih baik, hal ini di tunjukkan dengan data sebagian aktivitas sains kurang sesuai menjadi sesuai pada pembelajaran menggunakan LKSTabela. Aktivitas merumuskan masalah dan hipotesis, pada siklus I siswa membutuhkan banyak waktu untuk dapat melaksanakan langkah-langkah sains dan hasilnya juga belum sesuai, aktivitas menentukan alat dan bahan, merancang eksperimen dan membuat tabel siswa juga masih kurang mandiri, kurang kreatif dan sangat bergantung pada guru, aktivitas menganalisis data dan kesimpulan juga siswa masih belum sesuai seperti yang di harapkan guru. Namun, setelah siklus II aktivitas proses sains siswa menjadi lebih baik dan lebih sesuai dengan langkah-langkah proses sains. Siswa belajar nampak bersemangat karena gambar yang disajikan dalam LKS menarik perhatian siswa, siswa memberikan respon terhadap latihan dan pertanyaan yang disusun dan siswa belajar lebih mudah. Selain itu siswa juga lebih kompak bekerjasama dan mampu meningkatkan kemampuan berkomunikasi, mengemukakan pendapat dan mampu bertanya dengan baik dengan teman kelompok maupun kelompok lainnya.

\section{Hasil Tesketerampilan proses sainssiswa}

Sebelumdilaksanakanpembelajaran, guru melakukantesawalketerampilan proses siswa. Hasil tesawalsiswa rata-rata 59,75, setelahpembelajaran guru melakukantesakhirskor rata-rata siswamenjadi 89,5 dan peningkatan di uji dengan normalitas gain sebesar 0,82 kategoritinggi. Hasil tesketerampilan proses sainssiswa secara ringkasdisajikan pada tabel 3 berikut :

\section{Tabel 3 Hasil Tes Keterampilan Proses}

\section{SainsSiswa}

\begin{tabular}{|c|c|c|c|c|}
\hline $\mathrm{NO}$ & $\begin{array}{l}\text { Keterampilan Proses } \\
\text { Sains }\end{array}$ & $\begin{array}{c}\text { Pret } \\
\text { es }\end{array}$ & Postest & $\mathrm{N}$-gain \\
\hline I & $\begin{array}{l}\text { Membuat rumusan } \\
\text { masalah }\end{array}$ & 5,5 & 7 & 0,33 \\
\hline 2 & Membuat hipotesis & 5,5 & 7,5 & 0,44 \\
\hline 3 & Menggunakan alat bahan & 5,5 & 8 & 0,72 \\
\hline 4 & $\begin{array}{l}\text { Menyusun prosedur } \\
\text { kerja/merancang } \\
\text { eksperimen }\end{array}$ & 13 & 15 & 0,29 \\
\hline 5 & $\begin{array}{l}\text { Berkomunikasi (membuat } \\
\text { tabel) }\end{array}$ & $\begin{array}{c}12,7 \\
5\end{array}$ & 17 & 0,59 \\
\hline 6 & Menganalisis Data & II & 17 & 0,66 \\
\hline 7 & Kesimpulan & 6,5 & 18 & 3,29 \\
\hline $\begin{array}{l}\text { Skor } \\
\text { maks }\end{array}$ & 100 & $\begin{array}{c}59,7 \\
5 \\
\text { (kur } \\
\text { ang } \\
\text { sesu } \\
\text { ai) }\end{array}$ & $\begin{array}{c}89,5 \\
\text { (sesuai) }\end{array}$ & $\begin{array}{c}0,82 \\
\text { (tinggi) }\end{array}$ \\
\hline
\end{tabular}

Keterangan Skor:

- Skor 8-10 = sesuai

- $\quad$ Skor 6-7 = kurang sesuai

- Skor $\mathrm{I}-5=$ tidak sesuai

Peningkatan

sainspesertadidikkarena dengan LKS

Tabelayang digunakan guru sebagai media/bahan ajar telah di desain dengan langkahlangkah metode ilmiahatau dengan kata lain mengacu pada keterampilan proses sains yang meliputi, keterampilanbertanya(merumuskanmasalah), keterampilanmembuathipotesis,

menyiapkanalat dan bahan, merancang eksperimen/menyusun prosedur kerja, membuat tabel, menganalisis data dan membuat kesimpulan. Melalui pembelajaran menggunakan LKS Tabela siswa dapat belajar lebih maju karena siswadapatmengulangbelajarsendirisiswalebih mandiri dan lebihaktif dalam belajarnya. Hal inisesuaipendapat Kemp \& Dayton dalam AzharArsyad

lembarkerjasiswamemilikikelebihandiantarany a: I) siswadapatbelajar dan majusesuai dengan kecepatanmasing-masing; 
siswadapatmengulangbelajarsendirimateri yang sudahdisampaikan pada saatteori; 3) perpaduanteks dan gambarbisamenambahdayatariksehinggamemp erlancarpenyampaianinformasi yang disajikan dalam format verbal dan visual; 4) pesertadidikakanlebihaktifberpartisipasikarena harusmemberikanrespon terhadap latihan dan pertanyaan yang disusun.

Selain itu, melalui pembelajaran berbasis LKSTabela mampu meningkatkan hasil belajar siswa. Peningkatan hasil belajar siswa diduga karena melalui pembelajaran menggunakan LKS Tabelasiswa aktif dalam proses pembelajaran, siswa lebih mudah memahami materi yang diberikan. Hal ini sesuai fungsi LKS menurut Prastowo (2014) sebagai bahan ajar yang bisa meminimalkan peran guru dan lebih mengatifkan siswa, sebagai bahan ajar yang mempermudah siswa untuk memahami materi yang diberikan serta kompetensi keterampilannya, sebagai bahan ajar yang di ringkas dan mengandung unsur melatih keterampilan siswa dan mempermudah pelaksanaan pembelajaran.

Diagram peningkatanaktivitas Proses Sains, dan tesketerampilan Proses Sains, disajikan pada gambarl .

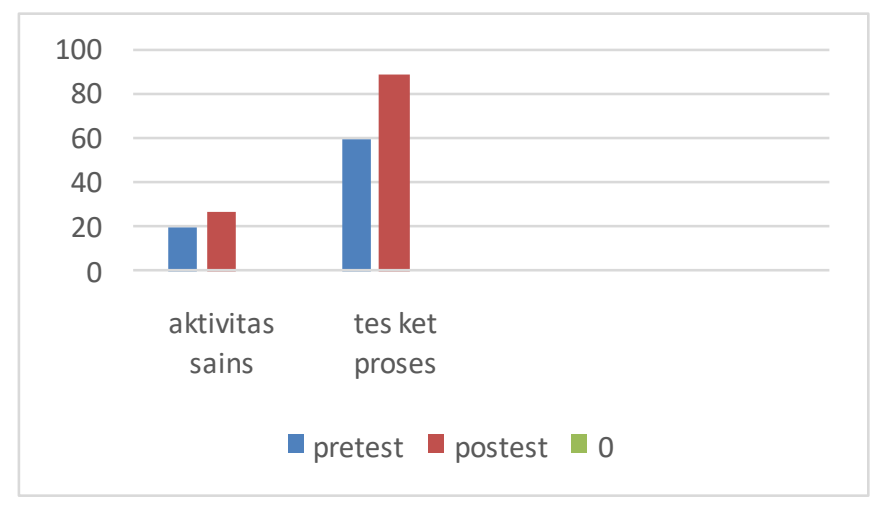

\section{KESIMPULAN}

I. Aktivitas belajar peserta didik aktif pada pembelajaran dengan menggunakan LKS berbasis Tabela.

2. PenggunaanLKS

Tabeladapatmeningkatkanketerampilan proses sainskelas $\mathrm{V} \quad \mathrm{di}$ SDMuhammadiyah Palangka Raya

\section{DAFTAR PUSTAKA}

Azhar, Arsyad. 2014. Media Pembelajaran. Jakarta: Raja Grafindo Persada Kemendiknas. 2013. Kurikulum 2013.Jakarta : Pusat Kurikulum.

Lestari,lka. 2013. Pengembangan Bahan Ajar berbasisKompetensi. Padang: Akademia

Nur, Mohammad. 20II. Modul KeterampilanKeterampilan Proses Sains. Surabaya: Pusat Sains dan MatematikaSekolah UNESSA.

Prastowo. 20I4. Panduan KreatifMembuat Bahan Ajar Inovatif. Yogyakarta: Diva Press.

Rezba, R.J, Sprague, C.S, Fiel, R.L, Funk HJ, Okey, J.R dan Jaus, H.H. (1999). Learning and Assesing Science Process Skill Third Edition.lowa : Kendall/Hunt Publishing Company.

Sanjaya, Wina. 2009. Media Komunikasi Pembelajaran. Jakarta: Kencana Persada Media Grup. 